Mieczysław Domaradzki związany byl również z naszym Instytutem. W zorganizowanych przez Niego badaniach nad Strumą brała udzial duża grupa studentów poznańskich, pod kierunkiem piszącego te słowa. Badania prowadziliśmy w okolicach całkowicie niedostępnych wtedy dla cudzoziemców, z czym łączyło się wiele dodatkowych przeżyć dostarczanych przez służby bezpieczeństwa. Mieczysław Domaradzki wykładał również w naszym Instytucie Prahistorii UAM, przedstawiając rezultaty swych znakomitych badań w Pistiros.

Mietek był wybitnym ,ambasadorem” Polski i polskiej archeologii w Bułgarii, ale także archeologii bułgarskiej w Polsce. Cześć Jego pamięci.

Tadeusz Makiewicz

\title{
WSPOMNIENIE O PROFESORZE MICHALE IWASZKIEWICZU
}

Dnia 2 lutego 2000 roku zmarł prof. dr hab. Michał Iwaszkiewicz, emerytowany kierownik Katedry Rybactwa Śródlądowego w poznańskiej Akademii Rolniczej.

Większości archeologów i prahistoryków w Polsce, a także i poza jej granicami, był znany przede wszystkim z prac badawczych nad pozostałościami szczątków ryb. Jako jeden z niewielu w kraju, a jedyny w Poznaniu, od początku lat 60 ., zajmował się między innymi badaniami archeoichtiologicznymi, zapoczątkowanymi w latach międzywojennych XX wieku przez prof. Edwarda Lubicza-Niezabitowskiego i dalej prowadzonymi przez Jego mistrza prof. Józefa Kaja. W ten sposób stał się Tym, który nie tylko kontynuował tradycję wspomnianych badań, ale również przyczynił się do ich rozwoju w poznańskim środowisku naukowym.

Należał do tego grona naukowców, któ-

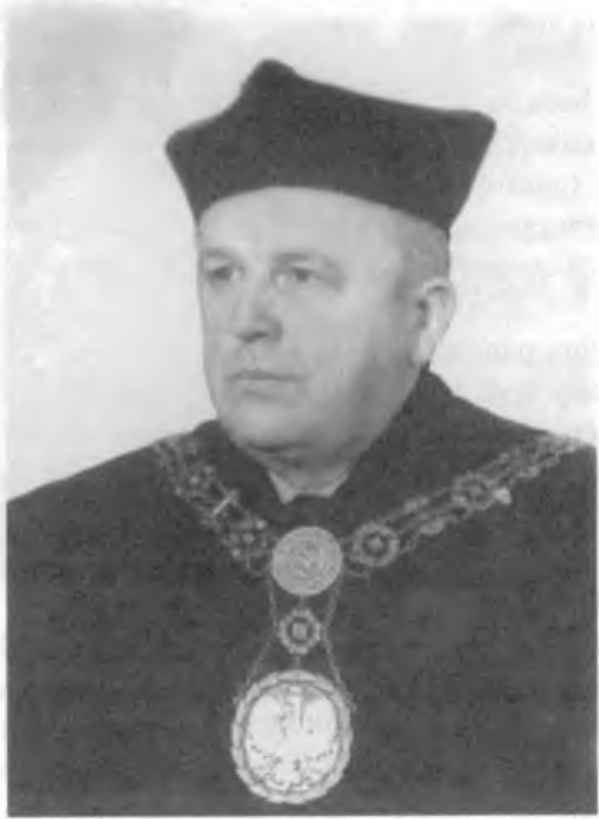
rzy poza szeroko rozwiniętą współpraca z przedstawicielami nauk przyrodniczych, umiejętnie nawiązywali kontakty naukowe i koleżeńskie między innymi $\mathrm{z}$ archeologami. Dowodem uznania dla Niego, ze strony środowiska archeologicznego, a szczególnie Muzeum Archeologicznego w Poznaniu, było przyznanie w 1977 roku, z okazji 120-lecia tegoż Muzeum, medalu pamiątkowego za zasługi dla rozwoju tej placówki.

W kontaktach z młodszym od siebie pokoleniem był jednym z tych mistrzów, którzy potrafili przekazywać swoją wiedzę $\mathrm{i}$ inspirowali do samodzielnej działalności. We współpracy $\mathrm{z}$ nimi prezentował umiejętność kreowania nastroju bliskiego koleżeństwa, podziwu oraz respektu dla Niego.

Profesor Michał Iwaszkiewicz urodził się 6 sierpnia 1922 roku w Wysławicach, w woj. poznańskim. Po uzyskaniu świadec- 
twa dojrzałości w 1946 roku, w Liceum Administracyjnym. podjął studia na Wydziale Rolniczo-Leśnym Uniwersytetu Poznańskiego.

Po uzyskaniu dyplomu inżyniera rolnictwa i tytułu magistra nauk agrotechnicznych z zakresu rybactwa, pracował jako ichtiolog w Państwowym Gospodarstwie Rybackim Wierzonka, a następnie w Zarządzie Okręgu Polskiego Związku Wędkarskiego w Poznaniu.

Pracę naukowo-dydaktyczną rozpoczął 15 kwietnia 1953 roku jako asystent w Katedrze Rybactwa Wyższej Szkoły Rolniczej w Poznaniu. W 1962 roku na Wydziale Zootechnicznym tej uczelni obronił rozprawę doktorską i uzyskał stopień doktora nauk rolniczych i leśnych.

W czerwcu 1966 roku habilitował się na Wydziale Rybactwa Morskiego Wyższej Szkoły Rolniczej w Szczecinie, otrzymując tytuł docenta nauk przyrodniczych w zakresie rybactwa śródlądowego. Od l stycznia 1968 roku objął kierownictwo Katedry Rybactwa Wyższej Szkoły Rolniczej w Poznaniu i kierował tą placówką aż do emerytury, na którą odszedł w 1992 roku. Przez cały ten okres oddawał się z wielkim zaangaźowaniem pracy naukowej, dydaktycznej, wychowawczej oraz społecznej. Wyrazem Jego działalności były liczne prace naukowe, pełnienie szeregu funkcji na uczelni oraz w towarzystwach i organizacjach naukowych.

Uchwałą Rady Państwa z dnia 4 marca 1976 roku otrzymał tytuł profesora nadzwyczajnego nauk rolniczych. W latach 1978-1982 pełnił funkcję dziekana Wydziału Zootechnicznego. Ponadto był wicedyrektorem Instytutu Zoologii Stosowanej. W 1984 roku, za osiagnięcia $w$ dziedzinie badań naukowych, otrzymał nagrodę zespołową I stopnia ministra nauki, szkolnictwa wyższego i techniki oraz zespołową nagrodę Urzędu Wojewódzkiego w Poznaniu - za osiagnięcia w dziedzinie rybactwa.

Był promotorem 4 przewodów doktorskich, 47 prac magisterskich oraz autorem 59 publikacji w czasopismach polskich i zagranicznych.

Jego aktywność naukowa i społeczna wyrażała się przynależnością i działalnością w wielu towarzystwach naukowych, muzeach i związkach, między innymi takich, jak: Poznańskie Towarzystwo Przyjaciół Nauk, Polskie Towarzystwo Zoologiczne, Sekcja Rybacka SITR-NOT w Poznaniu, Polski Związek Łowiecki, Polski Związek Wędkarski, Wielkopolski Park Narodowy, Polskie Towarzystwo Hydrobiologiczne, Muzeum Narodowe Rolnictwa i Przemysłu Rolno-Spożywczego w Szreniawie. W wielu z nich był nie tylko aktywnym członkiem, lecz pełnił funkcje przewodniczącego ich Rad.

Za swoją działalność został uhonorowany Złotym Krzyżem Zasługi, Krzyżem Kawalerskim Orderu Odrodzenia Polski, Medalem Komisji Edukacji Narodowej, Medalem Świętego Huberta, najwyższym odznaczeniem Polskiego Związku Łowieckiego - „ZŁOM” oraz wieloma odznaczeniami regionalnymi i resortowymi.

Śp. Profesor Michał Iwaszkiewicz do końca swoich dni zachowywał pełnię sił twórczych. Swoją aktywność naukową realizował pracując pilnie nad historią rybołówstwa śródlądowego w Wielkopolsce. Chociaż nie prowadził już osobiście badań archeoichtiologicznych, to żywo interesował się rozwojem tej dyscypliny. W dyskusjach ze mną jako badaczem młodego pokolenia, często dzielił się swoim fachowym doświadczeniem, przekazywał cenne uwagi oraz zawsze szczerze i życzliwie odnosił się do moich poczynań.

Był człowiekiem o niepowtarzalnej osobowości, szlachetnym i uczciwym. Takim pozostanie zawsze w sercach i pamięci tych, którzy się z Nim zetknęli. 


\section{BIBLIOGRAFIA PRAC ARCHEOICHTIOLOGICZNYCH}

1964 Szczatki ryb z grodziska (stan. 1) w Objezierzu, pow. Oborniki, „Fontes Archaeologici Posnanienses", vol. XV, s. 190.

1967 Szczatki rybie z miejscowości Szeligi, pow. Plock, (w:) W. Szymański, Szeligi pod Plockiem na poczatku wczesnego średniowiecza. Zespót osadniczy z VI-VII w., Wrocław, Warszawa, Kraków, s. 360.

1969 Szczatki ryb w materiale wykopaliskowym grodu $i$ osady podgrodowej w Drohiczynie pow. Siemiatycze, „Materiały Wczesnośredniowieczne”, t. 6, s. 237-239.

1975a Pozostatości ichtiologiczne z grodziska wklęstego w Bninie, pow. śremski, (w:) Materiały do studiów nad osadnictwem bnińskim. Grodzisko wklęste (red. J. Żak), Poznań, s. 199-200.

1975b Szczatki ryb z wczesnośredniowiecznego grodziska w Ujściu powiat Chodziez, „Roczniki Akademii Rolniczej w Poznaniu”, 76, Archeozoologia 1, s. 93-94.

1979a Szczatki ryb z podgrodzia w Bninie, (w:) Materiaty do studiów nad osadnictwem bnińskim. Podgrodzie (red. J. Żak J.), Warszawa. Poznań, s. 305-307.

1979b Szczatki ryb, (w:) Zaplecze gospodarcze konwentu OO. Franciszkanów w Inowroctawiu od potowy XIII w. do potowy XV w. (red. A. Cofta-Broniewska), Poznań, s. 176-177.

1980 Szczątki ryb z grodziska nad jeziorami Szczytno i Charzykowskim, „Roczniki Akademii Rolniczej w Poznaniu", 121, Archeozoologia 6, s. 3-6.

1985 Szczatki ryb z osady mezolityczno-neolitycznej w Dabkach koto Dartowa, „Roczniki Akademii Rolniczej w Poznaniu", 164, Archeozoologia 10, s. 3-6.

1988 Wyniki ekspertyzy ichtiologicznej niektórych zabytków z cmentarzyska kultury tużyckiej w Laskach, (w:) T. Malinowski, Laski. Materiaty z cmentarzyska kultury tużyckiej, cz. 1, Słupsk, s. 71.

1990 Szczątki ryb z wykopalisk Opactwa Benedyktynów w Lubiniu, woj. leszczyńskie, „Roczniki Akademii Rolniczej w Poznaniu”, 221, Archeozoologia 15, s. 3-8.

1991 Szczatki ryb z zamku krzyzackiego w Małej Nieszawce (woj. toruńskie), „Roczniki Akademii Rolniczej w Poznaniu", 227, Archeozoologia 16, s. 3-5.

1993 Szczatki ryb ze stanowiska Żmigród w Sandomierzu, (w:) Sandomierz. Badania 1969-1973, t. 1 (red. S. Tabaczyński), Warszawa, s. 378.

[wspólnie z:] Makowiecki D.

1995 Fish Skeletal Remains from Excavations at Novae (1988, 1990, 1993), „Archeologia", 46, s. 52--53.

Daniel Makowiecki

\section{Dr ERIKA NAGEL (31.12.1943-24.07.1999)}

24 lipca 1999 roku zmarła w Szwerinie po ciężkiej, dziesięcioletniej chorobie, dr Erika Nagel, była pracownica Museum für Ur- und Frühgeschichte w Szwerinie oraz wieloletni redaktor czasopisma „Jahrbuch für Bodendenkmalpflege in Mecklenburg(-Vorpommern)" i licznych innych publikacji archeologicznych. 